\title{
KEANEKARAGAMAN DAN DOMINANSI KOMUNITAS BULU BABI (ECHINOIDEA) DI PERAIRAN PULAU MENJANGAN KAWASAN TAMAN NASIONAL BALI BARAT
}

\author{
Gede Ari Yudasmara \\ Jurusan Budidaya Kelautan \\ Universitas Pendidikan Ganesha \\ Singaraja, Indonesia \\ e-mail : ari_yudasmara@yahoo.com
}

\begin{abstract}
Abstrak
Penelitian tentang keanekaragaman dan dominansi komunitas Bulu babi di perairan pulau Menjangan kawasan Taman Nasional Bali Barat telah dilakukan dari bulan Maret sampai Oktober 2012. Metode yang digunakan adalah metode transek kuadrat pada 3 lokasi pengamatan. Hasilnya menunjukkan bahwa jumlah jenis Bulu babi yang ditemukan di perairan sebelah selatan pulau Menjangan sebanyak 7 jenis yang terdiri dari Diadema setosum, Toxopneustes pileolus, Tripneutes gratilla, Echinometra mathaei, Salmacis belli, Pseudobolatia maculata dan Mespilia globulus dengan kategori keanekaragaman Bulu babi tergolong sedang yaitu $\mathrm{H}^{\prime}=1,9260$ dan dengan indeks dominansi jenis Bulu babi tertinggi adalah $\mathrm{C}=0,6052$ yang terkategori sedang.
\end{abstract}

Kata kunci: keanekaragaman, dominansi, Bulu babi

\section{Abstract}

A study of diversity and dominance sea urchin at Menjangan island West Bali National Park was done during March until October 2012. The methods using the quadrant transect method to monitor on 3 sample sites in Menjangan island. The result demonstrate that the amount of se urchin types in Menjangan island is 7 types. Sea urchin communities found were Diadema setosum, Toxopneustes pileolus, Tripneutes gratilla, Echinometra mathaei, Salmacis belli, Pseudobolatia maculata and Mespilia globulus. Diversity index of sea urchin is $H^{\prime}=1,9260$ and domain index is $\mathrm{C}=0,6052$ which falls under the medium category.

Key words: diversity, dominance, sea urchin

\section{PENDAHULUAN}

Indonesia sebagai negara kepulauan, telah dikenal memiliki kekayaan alam, flora dan fauna yang sangat tinggi. Ekosistem pesisir dan laut menyediakan sumber daya alam yang sangat produktif baik sebagai sumber kehidupan, sumber pangan, tambang mineral, kawasan rekreasi atau pariwisata (Bengen, 2000).

Salah satu bagian dari ekosistem tersebut dan memiliki peranan penting bagi kehidupan laut adalah Bulu babi. Bulu babi yang tergolong fauna invertebrata dapat ditemukan hampir diseluruh perairan pantai, mulai dari daerah pasang surut sampai pada perairan dalam. Bulu babi lebih menyukai perairan yang jernih dan airnya relatif tenang. Pada umumnya masing-masing jenis memiliki habitat yang spesifik, seperti zona rataan terumbu karang, daerah pertumbuhan alga, padang lamun, koloni karang hidup dan karang mati (Radjab, 2004).

Salah satu lokasi di Bali yang masih memiliki rataan terumbu karang cukup luas adalah Pulau Menjangan. Secara 
administratif pulau ini terletak di sebuah kawasan taman nasional, yaitu Taman Nasional Bali Barat (TNBB) dan secara fisik termasuk kategori pulau kecil karena merupakan pulau karang yang memiliki luas hanya $175 \mathrm{Ha}$ (TNBB, 2003).

Gambaran kondisi lingkungan seperti ini, sangat memungkinkan bagi Bulu babi untuk dapat hidup dan berkembang biak, hal ini didasari oleh karakteristik dari Bulu babi yang umumnya hidup pada substrat berupa karang maupun pecahan karang (rubble). Selain itu, hasil penelitian Yudasmara dan Kariasa (2009) juga menemukan bahwa di pesisir Pulau Menjangan terdapat daerah pertumbuhan alga dengan kepadatan mencapai $33 \%$, sehingga menunjukkan bahwa komunitas Bulu babi kemungkinan dapat ditemukan pada perairan tersebut. Penelitian ini bertujuan untuk: menganalisis keanekaragaman dan kelimpahan komunitas Bulu babi, jenis sedimen dan pengaruh faktor fisika kimia perairan terhadap keberadaan Bulu babi di perairan Pulau Menjangan.

\section{METODE}

Penelitian ini dilakukan di perairan sebelah Selatan Pulau Menjangan, kawasan Taman Nasional Bali Barat, dengan lokasi pengamatan meliputi 3 lokasi yaitu: pos I, pos II, dan pos III (Gambar 1). Untuk pengambilan data Bulu babi, digunakan metode transek kuadrat, dimana tali transek ditarik tegak lurus dari posisi titik surut terendah ke arah tubir karang sepanjang 100 meter, dengan digunakan frame kerangka besi berukuran $1 \times 1 \mathrm{~m}$. Titik plot pengamatan dilakukan tiap jarak 10 meter sepanjang garis transek, pengamatan dilakukan pada saat air menjelang surut. Setiap Bulu babi yang terdapat dalam kerangka frame tersebut dicatat jumlah jenis dan jumlah individunya serta mikrohabitatnya, sedangkan untuk lingkungan perairannya, seperti kecepatan arus, kedalaman, suhu, dan salinitas, diamati dengan menggunakan bantuan alat water quality checker.

Karakter komunitas seperti keanekaragaman jenis dan dominansi dapat ditelaah dengan menggunakan indeks diversitas Shannon-Wiener $(\mathrm{H})$ dan rumus dominansi Simpson (C) dari Setyobudiandi (2009) sebagai berikut:

$$
\begin{aligned}
& \mathbf{H}^{\prime}=-\sum\left(\frac{\mathrm{ni}}{\mathrm{N}} \ln \frac{\mathrm{ni}}{\mathrm{N}}\right) \\
& \mathbf{C}=\sum\left(\frac{\mathrm{ni}}{\mathrm{N}}\right)^{2}
\end{aligned}
$$

Keterangan :

$\mathrm{C}=$ Indeks dominansi

$\mathrm{H}^{\prime}=$ Indeks diversitas

$\mathrm{Ni}=$ Cacah/Jumlah individu spesies ke-i

$\mathrm{N}=$ Total individu di dalam komunitas 


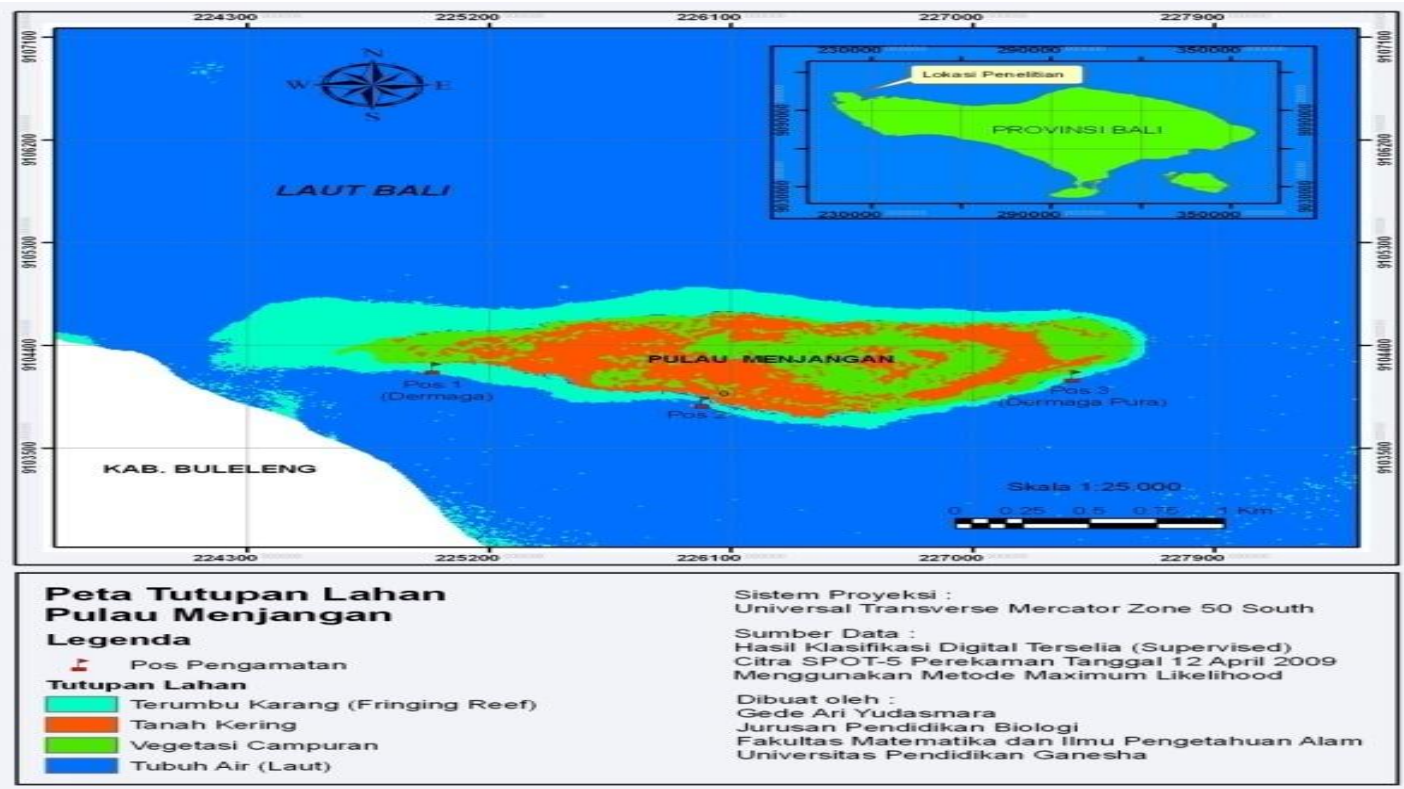

Gambar 1. Lokasi Pengamatan

\section{HASIL DAN PEMBAHASAN}

Dari hasil pengamatan dan pengambilan sampel di perairan Pulau Menjangan Taman Nasional Bali Barat, Bulu babi yang ditemukan sangat beragam dan hampir merata ditemukan pada setiap stasiun pengamatan. Kondisi pantai yang khas di Pulau Menjangan, dimana dikelilingi oleh hamparan karang yang memiliki kontur karangnya merupakan perpaduan dari berbentuk datar (flat) ke kontur yang tibatiba berubah drastis menjadi terjal atau dalam istilah selam disebut "drop off", ditambah dengan terdapatnya gua-gua pada dinding gugusan karang tersebut. Oleh karena itu, lokasi pengamatan hanya dilakukan pada bagian selatan pulau, karena hanya bagian ini yang memiliki hamparan pantai yang luas selebihnya berupa hamparan tebing-tebing karang yang curam.

Secara keseluruhan dari 3 stasiun pengamatan, yaitu Pos I, Pos II, dan Pos III, didapatkan 7 jenis Bulu babi yang hidup di perairan Selatan Pulau Menjangan.

Tabel 1. Nama Jenis Bulu Babi di Perairan Selatan Pulau Menjangan

\begin{tabular}{|c|c|}
\hline No & Nama IImiah \\
\hline 1 & Diadema setosum \\
\hline 2 & Toxopneustes pileolus \\
\hline 3 & Tripneutes gratilla \\
\hline 4 & Echinometra mathaei \\
\hline 5 & Salmacis belli \\
\hline 6 & Pseudobolatia maculata \\
\hline 7 & Mespilia globulus \\
\hline
\end{tabular}


Komposisi fauna pada setiap stasiun, menurut hasil pengamatan dan koleksi fauna Bulu babi pada tiga stasiun cukup bervariasi, dimana yang lebih banyak ditemukan adalah jenis dari Diadema setosum, sedangkan yang paling sedikit ditemukan adalah jenis Echinometra mathaei. Diadema setosum lebih banyak ditemukan karena mengingat profil substrat pantai di ketiga pos pengamatan lebih banyak karang, pecahan karang dan Bulu babi.

Secara kuantitatif data hasil transek disajikan pada Tabel 2. Dari analisa kuantitatif diperoleh suatu gambaran bahwa nilai indek diversitas (indek Shannon) tertinggi ditemukan pada stasiun II yaitu H' = 1,9260 sedangkan indeks dominansi tertinggi ditemukan pada stasiun I yaitu $\mathrm{C}=$ 0,6052 .

Tabel 2. Karakteristik Bulu babi Berdasarkan Beberapa Indeks Ekologis

\begin{tabular}{|c|c|c|c|c|c|c|c|c|c|}
\hline \multirow{3}{*}{ Parameter } & \multicolumn{9}{|c|}{ Lokasi } \\
\hline & \multicolumn{3}{|c|}{$\begin{array}{c}\text { Stasiun } \\
1\end{array}$} & \multicolumn{3}{|c|}{$\begin{array}{c}\text { Stasiun } \\
2\end{array}$} & \multicolumn{3}{|c|}{$\begin{array}{c}\text { Stasiun } \\
3\end{array}$} \\
\hline & 1 & 2 & 3 & 1 & 2 & 3 & 1 & 2 & 3 \\
\hline Jumlah je & 6 & 3 & 4 & 5 & 5 & 6 & 5 & 5 & 6 \\
\hline Jumlah individu & 10 & 4 & 8 & 8 & 8 & 9 & 8 & 7 & 8 \\
\hline Indeks Diversitas & \multicolumn{3}{|c|}{1.8708} & \multicolumn{3}{|c|}{1.9260} & \multicolumn{3}{|c|}{1.8852} \\
\hline Indeks Dominansi & \multicolumn{3}{|c|}{0.6052} & \multicolumn{3}{|c|}{0.5983} & \multicolumn{3}{|c|}{0.6012} \\
\hline
\end{tabular}

Bulu babi yang ditemukan jika dilihat dari jumlah individu dan jenisnya tidaklah terlalu banyak. Hal ini diakibatkan oleh persentase tutupan karang hidup di perairan Pulau Menjangan sebelah selatan relatif kurang baik. Banyak pasir, pecahan karang dan Bulu babi yang ditemukan di sepanjang pantai sebelah selatan pulau Menjangan. Kebanyakan Bulu babi hidup pada substrat yang keras, yakni batu-batuan atau terumbu karang dan hanya sebagian kecil yang menghuni substrat pasir dan lumpur, Disebabkan karena pada kondisi demikian kaki tabung sulit untuk mendapatkan tempat melekat. Disamping itu, kepadatan yang rendah atau kecil tersebut mungkin disebabkan oleh ketidakmampuan individu untuk menempati habitat dan juga disebabkan karena Bulu babi mengalami gangguan dari aktifitas penduduk, dimana pada lokasi pengamatan terdapat dua buah dermaga tempat untuk bersandarnya kapal boat serta di beberapa titik digunakan untuk aktivitas belajar snorkeling dan diving, hal ini juga ikut mempengaruhi persentase tutupan karang hidup di perairan Pulau Menjangan sebelah selatan yang kurang baik, sehingga mempengaruhi kehadiran Bulu babi disana.

Kehadiran populasi jenis ini penting bagi terumbu karang sebagai penyeimbang. Kesetimbangan populasi Bulu babi akan menjaga kesetimbangan populasi alga dan karang. Sedangkan kematian massal Bulu babi berdampak pada penurunan drastis tutupan karang. Selain itu, terumbu karang dapat didominasi oleh alga. Menurut Radjab (2004) ternyata ditemukan bahwa populasi Bulu babi yang sangat sedikit, pemulihannya membutuhkan waktu lebih dari 10 tahun. Hilangnya induk menyebabkan jumlah larva juga sangat kurang. Meski telah mulai ada pemulihan Bulu babi, namun belum dapat diketahui apakah akan dapat mengembalikan terumbu karang yang hilang (Darsono dan Toso, 2010).

Bulu babi adalah merupakan salah satu komponen penting dalam hal keanekaragaman fauna di daerah terumbu karang. Hal ini karena terumbu karang berperan sebagai tempat berlindung dan 
sumber pakan bagi fauna Bulu babi. Secara ekologi fauna Bulu babi berperan sangat penting dalam ekosistem terumbu karang, terutama dalam rantai makanan (food web), karena biota tersebut umumnya sebagai pemakan detritus dan predator. Ada empat macam habitat dari bentuk topografi daerah terumbu karang yaitu daerah zona pasir, zona pertumbuhan lamun dan rumput laut, zona terumbu karang dan zona tubir dan lereng terumbu.

Keanekaragaman Bulu babi yang ditemukan tergolong sedang karena berkisar pada skala 1 sampai 3 , dikatakan tinggi bila mencapai nilai 3 atau lebih. Begitu pula dengan dominansi yang terkategori sedang karena berada pada nilai kurang dari 1 , dikatakan tinggi apabila tinggi bila mencapai nilai 1. Kondisi ini lebih diakibatkan karena profil pantainya yang sebagian besar didominasi pasir dan pecahan karang serta Bulu babi, kurangnya keberadaan karang yang baik juga menyebabkan keanekaragaman Bulu babi menjadi relatif kurang. Beragamnya zona topografi pantai sepert zona pasir, zona pertumbuhan lamun dan rumput laut, zona terumbu karang dan zona tubir dan lereng terumbu, juga akan mempengaruhi keberagaman dari Bulu babi yang ada. Artinya semakin beragam tipe substrat maka semakin beragam Bulu babi yang ditemukan.

Pada Tabel 3 terlihat umumnya Bulu babi yang menyukai mikrohabitat pasir ada 4 jenis yaitu Diadema setosum, Tripneutes gratilla, Pseudobolatia maculata, dan Mespilia globulus, 5 jenis menempati mikrohabitat Bulu babi yaitu Diadema setosum, Tripneutes gratilla, Toxopneustes pileolus, Salmacis belli dan Mespilia globulus serta 5 jenis menempati mikrohabitat karang yaitu Diadema setosum, Toxopneustes pileolus, Echinometra mathaei, Salmacis belli, dan Pseudobolatia maculata.

Tabel 3. Penyebaran Bulu Babi Berdasarkan Mikrohabitat di Perairan

\begin{tabular}{|l|c|c|c|}
\hline \multicolumn{1}{|c|}{ Nama Jenis } & Pasir & Bulu babi & Karang \\
\hline Diadema setosum & $\sqrt{ }$ & $\sqrt{ }$ & $\sqrt{ }$ \\
\hline Toxopneustes pileolus & - & $\sqrt{ }$ & $\sqrt{ }$ \\
\hline Tripneutes gratilla & $\sqrt{ }$ & $\sqrt{ }$ & - \\
\hline Echinometra mathaei & - & - & $\sqrt{ }$ \\
\hline Salmacis belli & - & $\sqrt{ }$ & $\sqrt{ }$ \\
\hline Pseudobolatia maculata & $\sqrt{ }$ & - & $\sqrt{ }$ \\
\hline Mespilia globulus & $\sqrt{ }$ & $\sqrt{ }$ & - \\
\hline
\end{tabular}

Perairan pantai sebelah selatan Pulau Menjangan sebagian besar terdiri dari hamparan pasir, pecahan karang dan ditumbuhi makrolaga, meskipun ada dibeberapa titik dijumpai karang. Daerah berpasir dijumpai pada pos pengamatan 1 dan 3. Dasar perairan berpasir dan banyak terdapat hancuran karang dan ditumbuhi oleh makrolaga seperti dari jenis Halimeda sp, Caulerpa sp, Ulva sp dan Padina sp.

Komposisi sedimen atau substrat di lokaso pengamatan hampir serupa pada semua titik transek yaitu sebagian besar didominasi oleh pasir kasar dan pasir sangat kasar. Sedangkan cangkang moluska dan pasir halus merupakan sebagian kecil dari substrat. Hal ini merupakan habitat yang baik bagi Bulu babi dari famili Laganidae, karena dengan ukuran substrat yang didominasi oleh pasir kasar tersebut dpat memudahkan biota ini untuk beradaptasi maupun mencari makan. Famili Laganidae yang mendiami substrat pasir, berpindah dari suatu tempat ke tempat lainnya dengan 
menggunakan jari yang relatif pendek (short spine) untuk mencari makan (Radjab, 2004).

Selanjutnya dikatakan bahwa sebagian besar Bulu Babi mengkonsumsi alga, namun biota ini juga memakan mate3rial binatang yang telah mati yang diperoleh dari dalam pasir sebagai hasil ekstraksi lebih lanjut dari bahan organik. Ada beberapa Bulu babi hidup pada daerah yang bersubstrat agak keras, di daerah karang atau diantaranya batu-batu karang untuk berlindung dan untuk mencari makan. Ada juga yang hidup di substrat agak lunak dan bergerombol serta beradaptasi di daerah pasang surut.

Untuk kondisi ekologis perairan Pulau Menjangan, secara umum tergolong cukup baik. Hal ini terlihat dari berbagai jenis Bulu babi yang hidup, tersebar dengan cukup merata di Perairan Pulau Menjangan, sehingga hampir semua lokasi pengamatan ditemukan. Kondisi ini, kemungkinan disebabkan kualitas perairan Pulau Menjangan yang tergolong masih baik. Dari 7 parameter yang diuji (Tabel 4), tidak ada parameter yang melebihi atau melewati ambang batas baku mutu air laut untuk biota laut sesuai Kepmen Negara LH No. 51 tahun 2004.

Kondisi kualitas perairan ini tidak terlepas dari keadaan Pulau Menjangan yang tidak berpenduduk, letaknya yang cukup jauh dari mainland (Pulau Bali) dan berada di sekitar laut terbuka, sehingga limbah antropogenik tidak ada. Hal ini bisa dilihat dari parameter Amonia $\left(\mathrm{NH}_{3}\right), \mathrm{BOD}_{5}$ dan Turbiditas yang nilainya sangat rendah. Secara tidak langsung $\mathrm{BOD}_{5}$ merupakan gambaran kadar bahan organik yaitu jumlah oksigen yang dibutuhkan oleh bakteri aerob untuk mengoksidasi bahan organik menjadi karbondioksida dan air. BOD $_{5}$ merupakan salah satu indikator pencemaran organik pada suatu perairan, dimana perairan yang mempunyai nilai $\mathrm{BOD}_{5}$ tinggi mengindikasikan bahwa perairan tersebut telah tercemar oleh bahan organik. Bahan organik akan diuraikan secara biologis dengan melibatkan bakteri melalui sistem oksidasi aerobik dan anaerobik. Proses oksidasi aerobik akan menyebabkan terjadinya penurunan oksigen terlarut sampai pada tingkat terendah dan mengakibatkan kondisi perairan menjadi anaerob yang berdampak terhadap kematian organisme. Menurut Lee et al. 1978, tingkat pencemaran suatu perairan dapat dilihat berdasarkan nilai $\mathrm{BOD}_{5}$-nya yang terbagi dalam 4 (empat) kategori : (1) Nilai $\mathrm{BOD}_{5}<2,9 \mathrm{mg} / \mathrm{l}$ termasuk kategori tidak tercemar; (2) nilai $\mathrm{BOD}_{5}$ antara 3,0 $5,0 \mathrm{mg} / \mathrm{l}$ termasuk kategori tercemar ringan; (3) nilai $\mathrm{BOD}_{5}$ antara 5,1 - $14,9 \mathrm{mg} / \mathrm{l}$ termasuk kategori tercemar sedang; dan (4) nilai $\mathrm{BOD}_{5}>15 \mathrm{mg} / \mathrm{l}$ termasuk kategori tercemar berat, sehingga jika dibandingkan dengan hasil yang didapat maka perairan Pulau Menjangan masuk kategori belum tercemar.

Kehadiran Bulu babi di perairan Pulau Menjangan, tidak hanya ditentukan oleh kondisi biofisik dan kimia perairan tetapi juga karena media hidup dari bulu babi tersebut. Perairan Pulau Menjangan yang didominasi oleh terumbu karang yang cukup luas dan hidup mengelilingi Pulau Menjangan, telah menjadikan media hidup yang baik bagi Bulu babi. Karang dapat menjadi media hidup karena kaki tabung dari Bulu babi dapat melekat disela-sela karang, terutama pada substrat yang keras seperti pecahan karang (rubble), karang mati, serta bendabenda keras yang terendam di dasar laut. Keberadaan Bulu babi tersebut diperjelas dari hasil penelitian Yudasmara dan Kariasa (2008) dan Yudasmara (2010) yang memberikan gambaran bahwa pada ketiga stasiun pengamatan, ditemukan karang mati maupun pecahan karang (rubble) persentasenya cukup tinggi. Secara detail dapat dilihat pada Gambar 2 berikut ini. 


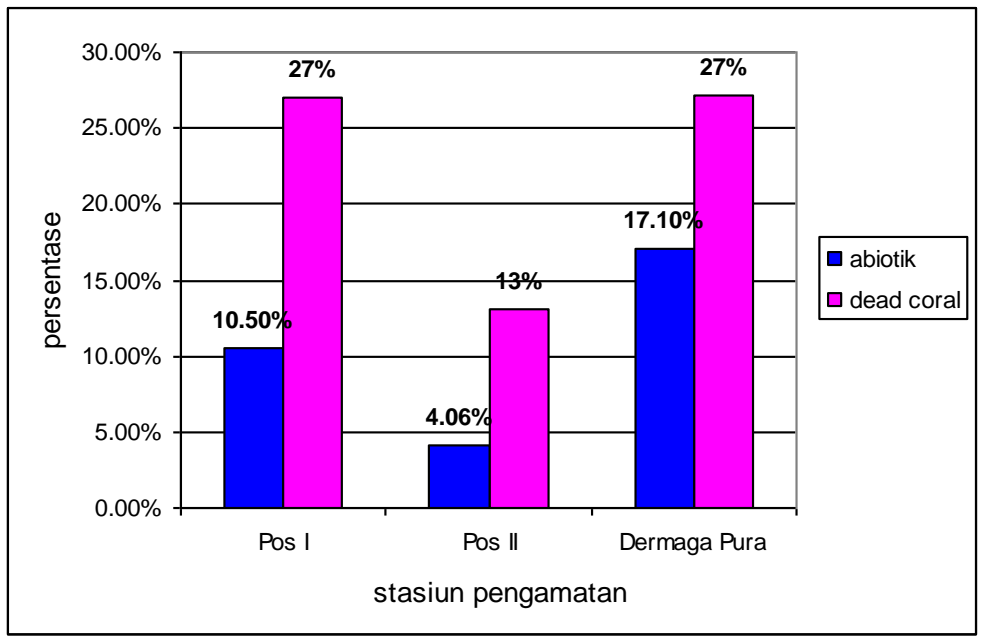

Sumber: Yudasmara (2010)

\section{Gambar 2. Persentase Komponen Abiotik dan Dead Coral di Pulau Menjangan}

Dari Gambar 2 di atas, terlihat bahwa persentase dead coral sebesar 22,44\% dan komponen abiotik 10,55 \% dari ketiga stasiun pengamatan yang cukup besar, maka kemungkinan kehadiran Bulu babi di perairan juga cukup besar, mengingat terdapatnya media untuk hidup.

\section{SIMPULAN}

Dari hasil pembahasan dapat disimpulkan beberapa hal antara lain :

1. Bulu babi yang ditemukan di perairan Pulau Menjangan terdiri dari 7 jenis yaitu: Diadema setosum, Toxopneustes pileolus, Tripneutes gratilla, Echinometra mathaei, Salmacis belli, Pseudobolatia maculata dan Mespilia globulus dengan keanekaragaman Bulu babi di perairan sebelah selatan Pulau Menjangan tergolong sedang dengan nilai indek diversitas tertingginya adalah $H^{\prime}=1,9260$ dan indeks dominansi jenis Bulu babi tertinggi adalah $C=0,6052$ yang terkategori sedang.

2. Tipe substrat yang dihuni oleh sebagian besar Bulu babi yang hidup di perairan Pulau Menjangan adalah tipe substrat karang dan substrat pertumbuhan alga, sedangkan tipe substrat pasir hanya sebagian kecil dari Bulu babi yang ditemukan.

3. Faktor fisika kimia perairan di perairan Pulau Menjangan tidak berpengaruh terhadap keberadaan Bulu babi, mengingat dari segi kualitas masih memenuhi kriteria hidup dari jenis Bulu babi.

\section{DAFTAR PUSTAKA}

Darsono P, Toso AV. 2010. Umur dan Pertumbuhan Bulu Babi Diadema setosum Leske di Perairan Terumbu karang Gugus Pulau Pari, Pulau-Pulau Seribu. Puslitbang Oseanologi LIPI. Jakarta.

Radjab AW. 2004. Sebaran dan Kepadatan Bulu Babi Di Perairan Kepulauan Padaido Biak Irian Jaya. Prosiding Seminar Laut Nasional III. Ikatan Sarjana Oseanologi Indonesia. Jakarta.

Radjab AW, Abraham SK, Jacobus WM, Prulley AU. 2010. Pengaruh Pemberian Pakan Terhadap Pertumbuhan dan Reproduksi Bulu 
Babi (Tripneustes Gratilla L). Jurnal Oseanologi dan Limnologi Indonesia. Vol 36 (2): 243-258.

Rokhmin D. 2003. Keanekaragaman Hayati Laut. Gramedia Pustaka Utama. Jakarta.

Setyobudiandi I. 2009. Sampling dan Analisis Data Perikanan dan Kelautan. MAKAIRA - FPIK IPB. Bogor.

TNBB (Taman Nasional Bali Barat). 2003. Information Kit.

Yudasmara AG, Kariasa N. 2008. Analisis Ekosistem Terumbu Karang Di
Pulau Menjangan Kawasan Taman Nasional Bali Barat. Laporan Penelitian DIPA. Universitas Pendidikan Ganesha. Bali.

Yudasmara AG, Kariasa N. 2009. Analisis Komunitas Makroalga Di Perairan Pulau Menjangan Kawasan Taman Nasional Bali Barat. Laporan Penelitian DIPA. Universitas Pendidikan Ganesha. Bali.

Yusron E, 2010. Keanekaragaman Jenis Ekhinodermata Di Perairan Teluk Kuta Nusa Tenggara Barat. Jurnal Makara Sains. Vol 13 (1): 45-49. 